\title{
CLIMATIC LIMITS OF TROPICAL AFRICAN HONEYBEES IN THE AMERICAS
}

\author{
by Orley R. Taylor, Jr, and Marla Spivak \\ Department of Entomology*, University of Kansas, Lawrence, KS 66045, USA
}

When a pest species is introduced into a new environment, immediate concerns are the geographical range it will occupy and the relative impact it will have in different habitats. Relative densities and impact are difficult to predict, but several attempts have been made to predict geographical limits of invading species based on the climatic extremes the species experiences in its native habitats ${ }^{2}, 3$. In theory such predictions should work, since an organism should not be able to tolerate conditions more extreme than those under which it evolved.

The introduction of the tropical African honeybee (Apis mellifera scutellata) into South America presents this type of problem. In 1977 one of us (O.R.T.) predicted the limits these bees might reach in the USA, based on what was known of climates experienced by them in South Africa and Argentina ${ }^{10}$. Although the precise limits of distribution in these countries were not known, it appeared that the bees were occupying areas where they experienced:

1. short intervals with temperatures as low as $-10^{\circ} \mathrm{C}$

2. 6-8 weeks with mean temperatures of $10^{\circ}$ and mean maxima of $17^{\circ}$ and minima of $4^{\circ}$

3. up to, and perhaps more than, 60 days a year with freezing temperatures

4. up to, and perhaps more than, 150 days between the first and last frosts (a 215-day growing season).

However, the bees did not appear to have become permanently established in areas where climatic factors were more extreme than those listed. At the time the assessment was made (1975) it was not known which factor, or combination of factors, would most satisfactorily describe the limits of a permanent population of the African bees. The best indicators seemed to be either an isotherm at which the mean temperature for the coldest months was $10^{\circ}$, or a line at which there were 240 frost-free days. These climatic measures were chosen because they are similar over broad areas. However, the correlation between the two lines breaks down along the coasts, the 240 frost-free day line running far north of the $10^{\circ}$ line on both coasts of the USA. In Argentina the 240 frost-free day line runs about $320 \mathrm{~km}$ further south along the coast than the $10^{\circ}$ isotherm, which traverses western Argentina from Salta to Cordoba and then south-east to Buenos Aires (Fig. 1). The purpose of this paper is to reassess the value of these climatic features as predictors of the prospective limits of tropical African bees in the USA.

\footnotetext{
${ }^{*}$ Contribution No. 1847 from the Department of Entomology, University of Kansas, Lawrence, KS 66045, USA

${ }^{\dagger}$ A.m. scutellata (formerly adansonii) refers to the lowland honeybees of central and southern Africa, exclusive of littorea of East Africa (Tanzania), adansonii of West Africa (Senegal) and capensis of the Cape area of South Africa.
} 


\section{Present distribution of tropical African bees in Argentina}

African bees entered northern areas of Argentina in the late 1960s, and were apparently established from Salta to Cordoba in the north-west and north-central areas before $1973^{5,6,8}$. Their boundary was similar to the $10^{\circ}$ mean isotherm for July reported earlier ${ }^{10}$. The time at which they penetrated the eastern area (e.g., the vicinity of Rosario) was unclear in the mid-1970s, and it is still uncertain.

Three useful distribution lines have been produced for African bees in Argentina ${ }^{6}$ (Fig: 2). The lines form the southern boundary of the zones in which:

1. all feral and managed bees are African in appearance and behaviour throughout the year

2. colonies of African bees can overwinter (it was estimated ${ }^{6}$ that about $30 \%$ of the colonies were African in this area)

3. colonies can survive to the end of the growing season, but not overwinter.

Movement of bees south of line 2 is determined by shipments of queens and colonies to take advantage of seasonal honey flows ${ }^{6}$. There may also be some dispersal of swarms into these regions from the zone where the feral population survives the winters. Line 2 appears to have been stable since 1973 or earlier, which suggests that it represents a meaningful biological barrier. Intense selection may be preventing African bees from overwintering south and west of this line, and we shall discuss the physical and biological factors which may be involved.

The L-shaped boundary of the overwintering distribution (line 2 in Fig. 2) is due to the influence of the Andes in the western part of Argentina, which modify the climate so that it is colder in the foothills than in the lowlands to the east. Fig. 1 shows how the isotherms parallel the mountains from north to south and then swing east across the plains towards Buenos Aires. Comparison of these isotherms (Fig. 1) with the overwintering zone (Fig. 2) shows that the latter does not closely correspond with the 240 frost-free day line, or with the $10^{\circ}$ isotherm used by Taylor ${ }^{10}$.

The temperatures for all weather stations along line 2 that delineates the overwintering population are given in Table 1 . The overwintering zone does not correlate well with absolute minimum temperatures, which range from $-4 \cdot 0^{\circ}$ to $-9 \cdot 5^{\circ}$, with mean minima $\left(0 \cdot 1^{\circ}\right.$ to $\left.5 \cdot 3^{\circ}\right)$, or with daily means $\left(7 \cdot 6^{\circ}\right.$ to $\left.12 \cdot 6^{\circ}\right)$. The best correlation appears to be with the $16^{\circ}$ mean high temperature for the coldest month (July). All the recording stations north of line 2 (except San Luis) have mean high temperatures above $16^{\circ}$, and those south of it have lower mean high temperatures. The fit of the $16^{\circ}$ isotherm and the limit of the overwintering zone is general, not specific: temperatures and survival of the bees vary from year to year. Obvious discrepancies between the $16^{\circ}$ isotherm and the distribution ${ }^{6}$ (such as west of Salta and Catamarca) may reflect the difficulties of representing these distributions on a small map rather than inaccuracy of data. Other discrepancies, as in the south-central area (south of Cordoba), may be due to the presence of small mountains which influence the climate locally. Detailed on-site observations are needed to establish whether African bees permanently occupy the cooler regions south of the $16^{\circ}$ isotherm. If so, it would imply that the bees are more cold hardy than elsewhere along the overwintering line, and we would have to explain why they have not invaded areas to the east, including the northern half of Buenos Aires Province, during the last 10 years. 


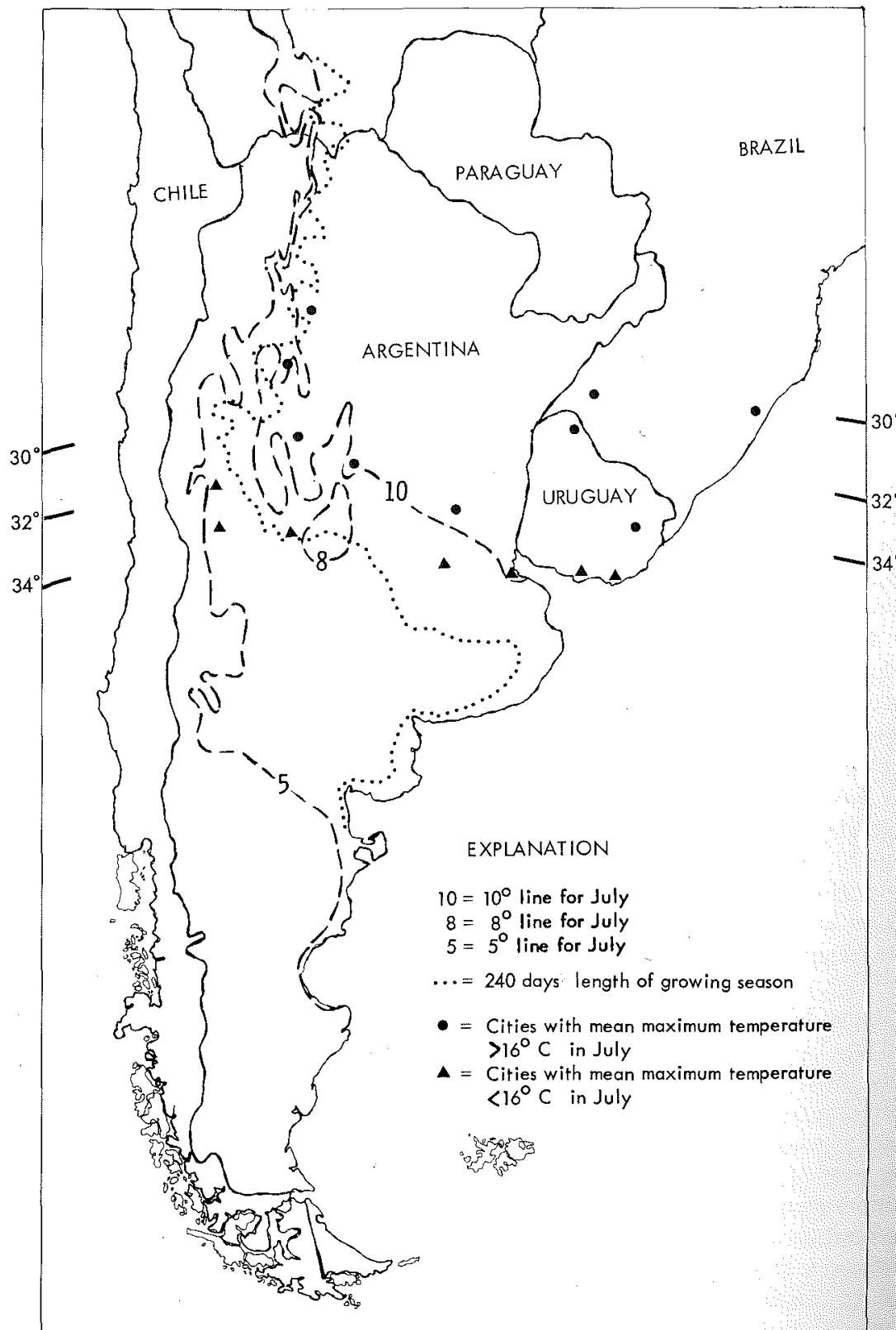

Fig. 1. Climatic features of the zone occupied by tropical African honeybees in southern South America.

$30^{\circ}, 32^{\circ}, 34^{\circ}$ are latitudes south of the equator. 


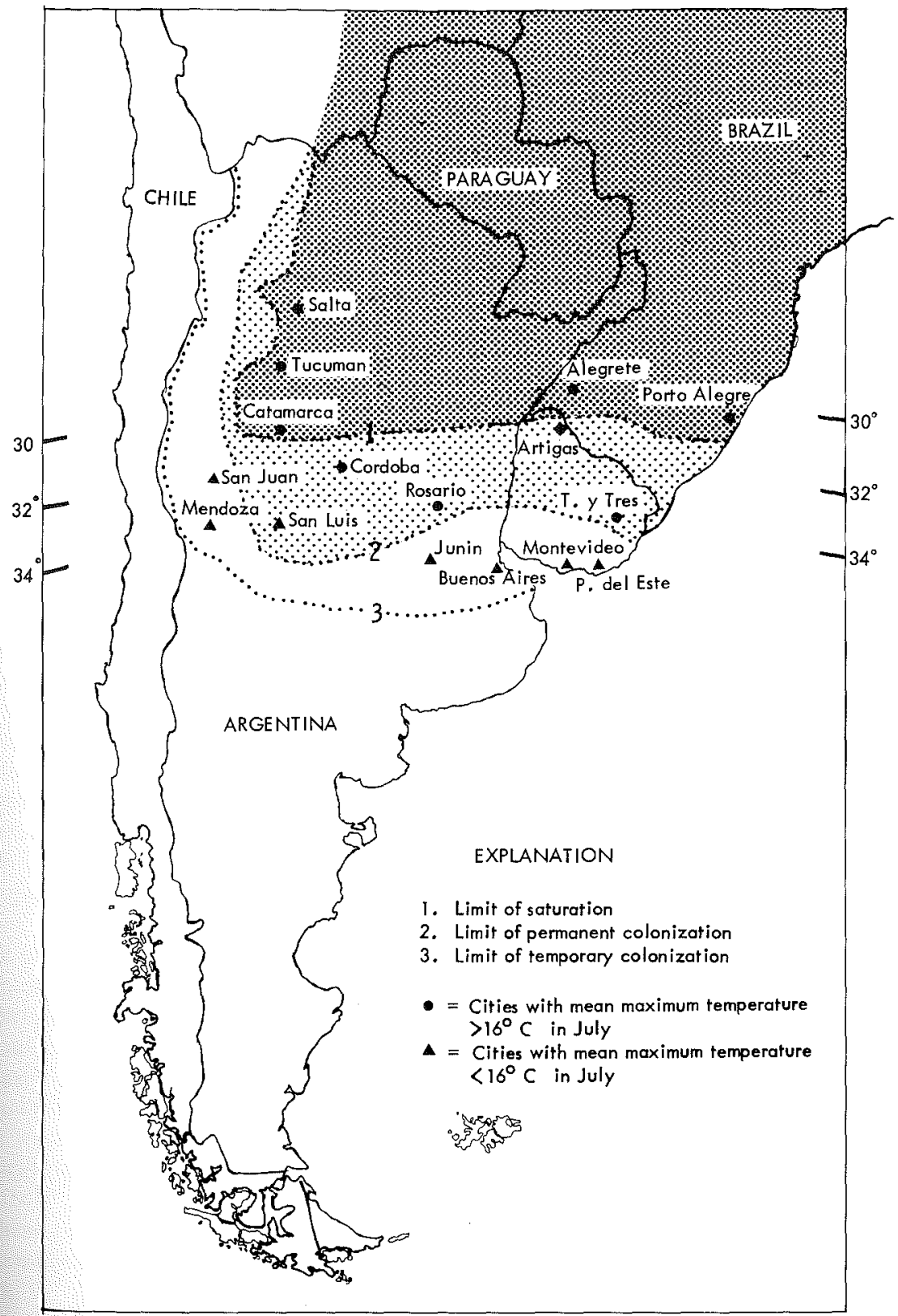

Fig. 2. Distribution of tropical African honeybees in southern South America. Redrawn from Kerr et al. $1982^{6}$. 
TABLE 1. Mean and extreme temperatures $\left(\mathrm{C}^{\circ}\right)$ expected annually during the coldest month (July) in zones colonized by tropical African honeybees in southern South America.

\begin{tabular}{|c|c|c|c|c|c|c|c|c|c|c|c|c|c|c|c|c|}
\hline & \multicolumn{10}{|c|}{$A R G E N T I N A$} & \multicolumn{4}{|c|}{$U R U G U A Y$} & \multicolumn{2}{|c|}{$B R A Z I L$} \\
\hline & 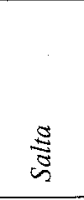 & 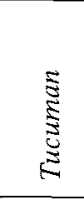 & 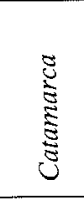 & $\underset{5}{5}$ & 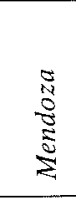 & $\begin{array}{l}3 \\
5 \\
5 \\
5 \\
5\end{array}$ & $\begin{array}{l}5 \\
0 \\
0 \\
0 \\
0 \\
0\end{array}$ & $\begin{array}{l}0 \\
\frac{1}{8} \\
0 \\
0 \\
0\end{array}$ & $\stackrel{5}{S}$ & $\begin{array}{l}3 \\
\frac{2}{7} \\
0 \\
0 \\
0 \\
0 \\
0\end{array}$ & 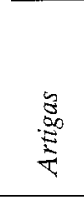 & $\begin{array}{l}5 \\
3 \\
5 \\
E \\
E\end{array}$ & 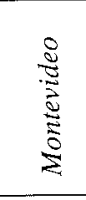 & 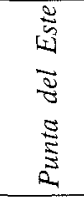 & 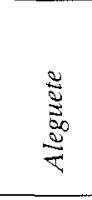 & $\begin{array}{l}0 \\
20 \\
\stackrel{4}{4} \\
8 \\
0 \\
0\end{array}$ \\
\hline mean max. & $19 \cdot 5$ & $19 \cdot 9$ & $19 \cdot 8$ & $16 \cdot 1$ & $13 \cdot 0$ & $15 \cdot 9$ & $18 \cdot 0$ & $16 \cdot 1$ & $15 \cdot 2$ & $14 \cdot 7$ & $19 \cdot 1$ & $16 \cdot 8$ & $14 \cdot 6$ & $14 \cdot 2$ & $18 \cdot 2$ & $19 \cdot 0$ \\
\hline mean min. & $2 \cdot 8$ & $5 \cdot 3$ & $3 \cdot 2$ & $-0 \cdot 1$ & $2 \cdot 2$ & $1 \cdot 7$ & $3 \cdot 2$ & $4 \cdot 6$ & $4 \cdot 4$ & $6 \cdot 3$ & $8 \cdot 1$ & $6 \cdot 6$ & $6 \cdot 3$ & $8 \cdot 5$ & $7 \cdot 6$ & $9 \cdot 6$ \\
\hline daily mean & $11 \cdot 1$ & $12 \cdot 6$ & $11 \cdot 4$ & $8 \cdot 0$ & $7 \cdot 6$ & $8 \cdot 8$ & $10 \cdot 6$ & $10 \cdot 2$ & $9 \cdot 8$ & $10 \cdot 5$ & $13 \cdot 6$ & $11 \cdot 7$ & $10 \cdot 5$ & $11 \cdot 4$ & $12 \cdot 9$ & $14 \cdot 3$ \\
\hline extreme max. & $33 \cdot 1$ & $37 \cdot 3$ & $37 \cdot 4$ & $34 \cdot 0$ & $27 \cdot 9$ & $28 \cdot 6$ & $33 \cdot 2$ & $28 \cdot 0$ & $27 \cdot 3$ & $27 \cdot 6$ & $29 \cdot 5$ & $28 \cdot 0$ & $28 \cdot 5$ & $25 \cdot 8$ & $30 \cdot 4$ & $32 \cdot 9$ \\
\hline extreme min. & -9.5 & $-4 \cdot 8$ & $-9 \cdot 0$ & $-.7 \cdot 3$ & $-6 \cdot 2$ & $-9 \cdot 4$ & $-9 \cdot 2$ & -9.5 & -6.0 & $-5 \cdot 3$ & -4.0 & -4.0 & -5.0 & -0.4 & $-5 \cdot 0$ & -1.5 \\
\hline
\end{tabular}


An alternative view might be that the $16^{\circ}$ isotherm is coincidental and that the distribution is defined by biological factors that are independent of temperature. We favour the former interpretation since $16^{\circ}$ is very close to the $17^{\circ}$ mean maximum temperature which seems to define the distribution of tropical African bees in South Africa. ${ }^{10}$.

\section{Prospective distribution of African bees in the USA}

If the overwintering distribution ${ }^{6}$ is correct and our interpretation is valid, the $16^{\circ}$ mean high-temperature isotherm for January would be a better predictor of the eventual distribution of tropical African bees in the USA than the 240 frost-free day line or the $10^{\circ}$ isotherm for January. These features are well correlated over most of the USA, although the $16^{\circ}$ line $\left(60^{\circ} \mathrm{F}\right.$ in Fig. 3$)$ is more restricted along the coasts, the prospective northern limit of African bees being Santa Cruz, California, on the west coast and the vicinity of Clinton (near Fayetteville), North Carolina, on the east coast.

It is important to emphasize that the northern limit of tropical African bees in the USA will not be static. Winter conditions are not constant from year to year, and areas at the edge of the range where these bees survive through one winter may be unsuitable in another. Also, in the USA African bees are likely to be spread by man, or naturally, beyond the overwintering region. Although such bees will die out during most winters, any bees beyond the overwintering zone will help to broaden a zone of hybridization between African and European bees, that will become established. Thus, the direct effects of this introduction are likely to extend beyond the overwintering region.

One important point ${ }^{6}$ is that there is a zone of saturation in which virtually all feral and managed bees are tropical African. South of this zone in South America, and as far as the southern limit of the overwintering zone, it is estimated ${ }^{6}$ that only $30 \%$ of the colonies are 'aggressive'-and by implication are therefore African bees. This is probably an underestimate, since not all African colonies are highly defensive, and no doubt there is a good deal of variation in behaviour and in the number of African colonies, due to seasonal conditions. Such distinctions do make the point, however, that some habitats favour African bees while others are marginal. Because the impact of these bees is likely to be determined by the number of feral colonies per unit area, it is also important to establish what physical or biological factors are associated with the zone of saturation. Unfortunately, few climatic data are available for this region; however, the line marking its southern limit appears to be similar to a $19^{\circ}$ mean high-temperature isotherm for the coldest months (June and July). Each of the recording stations on or north of this line has mean high temperatures of at least $19^{\circ}$ for the coldest months while those south of the line have lower temperatures (Table 1). Extending this to the USA, it seems possible that tropical African bees will saturate those areas with mean maximum temperatures above $19^{\circ}\left(66^{\circ} \mathrm{F}\right.$ in Fig. 3) during the coldest months (January-February).

These projections have serious implications for the honeybee industry in the USA, since more than $90 \%$ of the queens and package bees are currently produced in the area south of the prospective overwintering line (Fig. 3) ${ }^{11}$. Apiculture has changed substantially in all areas of South America where African bees have established high density feral populations. In such areas all the European bees are hybridized out of existence within 2-3 years, and it has proved impossible to maintain pure European 


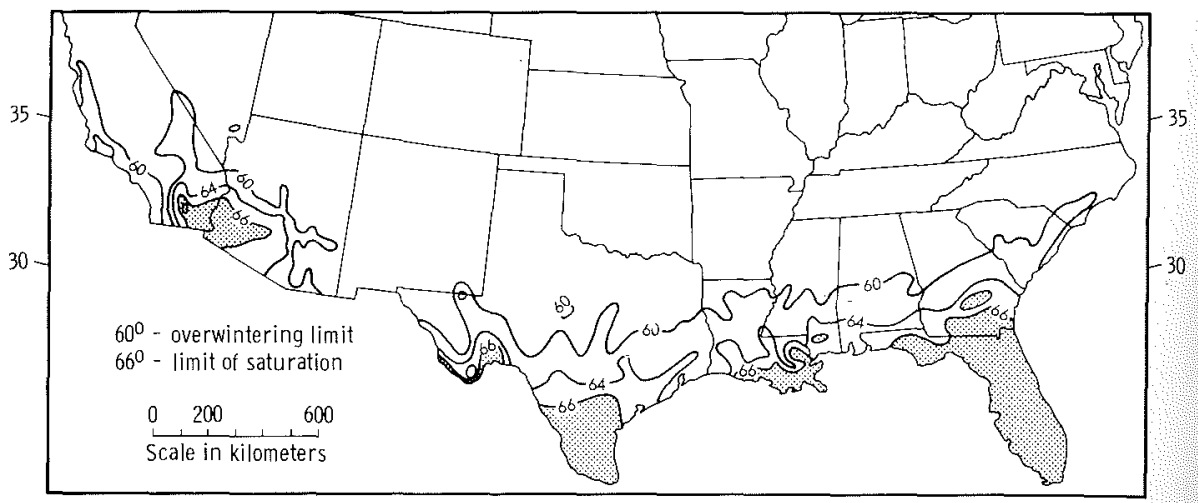

FIG. 3. Prospective limits of tropical African honeybees in the USA.

$30^{\circ}, 35^{\circ}$ are latitudes north of the equator.

$60^{\circ}, 66^{\circ}$ are temperatures in ${ }^{\circ} \mathrm{F}\left(15^{\circ}, 19^{\circ} \mathrm{C}\right.$, respectively).

stocks, except by frequent introduction of queens produced in regions free of African bees, or through instrumental insemination. This is evidently not the case within the area between the zone of saturation and the overwintering limit, since European bees still persist here even though African bees have been present for 12-14 years ${ }^{6}$. There could be several explanations for this; the simplest may be that the majority of African colonies die out, or else abscond and migrate to warmer regions each winter. The number of colonies would then build up slowly during the warmer months, as the surviving colonies swarm and new colonies become established from swarms that have migrated from warmer climates. The population of African colonies would therefore reach a peak after most of the swarming and mating by European queens. Under these conditions the mating advantage of African bees in the tropics - because of the greater abundance and temporal and spatial distribution of their drones ${ }^{12}$-would be diminished. Few European queens would mate with African drones. African queens mate later in the day, when few European drones are flying ${ }^{13}$, so they would mate predominantly with African drones, and would thus be able to persist as a distinct population in areas dominated by European bees. This same phenomena could develop in the southern USA (Fig. 3). African bees could invade and possibly saturate areas south of the $19^{\circ}$ isotherm, but would occur permanently and at lower densities as far north as the $16^{\circ}$ isotherm (Fig. 3). Their effect on queen rearing and the package bee industry within these regions could be determined by many non-biological factors. But from the standpoint of the interaction between two populations, we would expect the most serious problems to develop where African bees maintain the highest densities, and where their colony population increases rapidly in the spring.

\section{Factors involved in successful overwintering of African bees}

The limits of the permanent African honeybee population in Argentina are most likely to be defined by the following differences from European bees:

1. the smaller size of the feral colonies 
2. the limited amount of honey stored in these colonies

3. the higher metabolic rate of workers and the more rapid consumption of stores

4. the limited availability of nectar sources and temperatures suitable for foraging during the coldest months.

One of the most interesting possibilities is that the overwintering success of tropical African bees could be determined by an interaction between the reduced lifespan of adults ${ }^{16,18,20}$ and the duration of the broodless period during the coldest months. Winston ${ }^{15},{ }^{16}$ has shown that, when colonies are active, the mean lifespan of adult African workers varies from 12 to 28 days depending on the availability of pollen and nectar resources. The bees live longer during colder conditions. Woyke ${ }^{20}$ noted that with overwintering tropical African bees maintained indoors, mortality increased rapidly after 3 months. No correlation has been demonstrated between climate and the length of broodless period for African bees; nevertheless it seems possible that colonies of bees with a relatively short adult life ( $<100$ days) during winter, that were broodless for $1-2$ months, could die out even in the presence of adequate stores.

In colder regions the small size of feral African colonies, and their limited honey storage, are probably important for their survival. We have dissected and measured more than 70 feral African colonies in French Guiana, Peru and Venezuela ${ }^{14}$. The colonies were usually small, the average comb surface area per colony in Peru being $8000 \mathrm{~cm}^{2}$ at the time of first swarming ${ }^{17}$ - slightly less than that of 4.4 Langstroth frames. By contrast, the comb area in European colonies averaged $15806 \mathrm{~cm}^{2}(9 \cdot 6 \text { frames })^{16}$. In Venezuela the average comb area of mature feral African colonies was much larger $\left(11255 \mathrm{~cm}^{2}\right)$, but the largest colonies had only $21187 \mathrm{~cm}^{2}(12.5$ frames). If we assume that the limits of survival are determined by the largest colonies with the greatest stores, and that the combs are $75 \%$ filled with honey $(2 \cdot 1 \mathrm{~kg}$ per frame-equivalent since African combs are thinner than European), then the maximum honey storage capacity of feral African colonies would be close to $19 \mathrm{~kg}$.

Feral colonies in French Guiana and Peru contained less than $2.5 \mathrm{~kg}$ honey on the average, and in Venezuela the amount was usually only $5-7 \mathrm{~kg}$.

We conclude that for feral African bees, with small nests, limited honey storage capacity, and short adult lifespan, the $16^{\circ}$ line may define the limit of distribution because slightly colder climates may be correlated with a greater suppression of plant growth and of nectar production, a greater number of consecutive days of confinement and total number of days of confinement during winter, a longer broodless period, and a smaller number of days with temperatures high enough to allow foraging or to permit relocation of the bees over honey stores within the nest.

The question often arises ${ }^{1}$ as to whether African bees might acquire overwintering abilities from European bees, and so expand their distribution further into temperate regions. While this might occur, we believe it is unlikely. As indicated above, an important factor in the success of tropical African bees is the partial reproductive isolation by time of day at which mating occurs. In the absence of such isolation, invasions by low-density African bee populations into areas with large numbers of European colonies would be diluted; African traits, if they were adaptive, would be incorporated into the gene pool of the European population. However, traits that were maladaptive, such as inability to overwinter, would be selectively eliminated. 
For African bees to acquire a European trait, such as overwintering ability, they must maintain their partial reproductive isolation. Further, queens resulting from a European queen $\times$ African drone cross must mate predominantly with African drones. This is precisely what is happening in the tropical areas ${ }^{12}$, but European traits are not acquired because they do not confer higher fitness. If we were to rank the crosses on the basis of their overall survival value in tropical regions, pure African crosses would survive best, various hybrid crosses would be intermediate, and pure European crosses would survive least. At the limit of the distribution (e.g., Argentina) the survival ranking would be reversed, pure European crosses surviving best and pure African least. The ability of the population with the lowest fitness to acquire traits from the population with higher fitness would be determined by the magnitude of the relative difference (selective coefficients) between the survival of the different crosses. If the selective gradient is steep, and the characters conferring survival through the winter (such as cell size, bee size, intercomb distance, nest size, honey storage, metabolic rate, cluster efficiency) are polygenic or are inherited as coadaptive gene complexes, the likelihood that such traits will be acquired rapidly by the 'inferior' population is low.

The possibility that European bees outside the overwintering zone of African bees will acquire from them traits such as defensive behaviour through introgressive hybridization is also of interest. Adaptive traits that assort independently of the linkage groups or adaptive gene complexes that maintain the essential African phenotype could introgress into the feral and managed European bee population if they contribute to the survival of European colonies. However, our knowledge of the genetic differences between these races is too limited to predict which, if any, such traits will be acquired by European bees.

Although the conclusions in this article are speculative, similar speculations concerning the rate of spread of African bees in Central and South America have been fairly accurate ${ }^{9}, 10$, and climatic limitations have been accurately predicted for other invading species of social insects ${ }^{2}$. In the USA, because of the types of habitat and climatic conditions, and the likely path of African bees through Mexico into Texas ${ }^{10}$, it is in west central Texas that African bees will probably first reach their climatic limits. The overwintering line in this region will be useful for predicting the climatic limits throughout the rest of the USA.

\section{Acknowledgements}

Some of the information used in this article was obtained with the support of United States Department of Agriculture Cooperative Agreement 58-7B30-8-7 and Research Agreement 12-14-7001-363.

\section{References}

1. Anonymous (1982) The improvident bee. Scient. Am. $247: 92$

2. Buren, W. F.; Allen, G. E.; Whitcomb, W. H.; Lennartz, F. E.; Williams, R. Y (1974) Zoogeography of the imported fire ants. J. N.Y. ent. Soc. 82 . 113-124

3. Fox, H. (1939) The probable future distribution of the Japanese beetle in North America. J. N.Y. ent Soc. $47: 105-125$

4. Heinrich, B. (1979) Thermoregulation of African and European honeybees during foraging, attack, and hive exits and returns. J. exp. Biol $80: 217-229$

5. Katzenelson, M.; Cornejo, L.; Onetti. Personal communication 
6. Kerr, W. E.; Leon Del Rio, S. de; Barrionuevo, M. D. (1982) The southern limits of the distribution of the Africanized honey bee in South America. Am. Bee J. $122: 196-198$

7. Otis, G. W.; Winston, M. L.; Taylor, O. R. (1981) Engorgement and dispersal of Africanized honeybee swarms. $J$, apic. Res. $20: 3-12$

8. Rinaldi, A. J. M.; Popolizio, E. R.; Pailhé, L. A. (1970) El problema de la 'abeja africanizada' en el noroeste Argentina. 1 Congr. Bras. Apic. : 298-300

9. Robinson, F. (1981) Africanized bees: A problem that won't go away. Am. Bee J. $121: 625-626$

10. TAYLOR, O. R. (1977) Past and possible future spread of Africanized honey bees in the Americas. Bee Wld 58 : 19-30

11. unpublished survey

12. TAYloR, O. R.; Kingsolver, R. W.; OtIS, G. W., in preparation

13. Taylor, O. R.; Otis, G. W.; KukuK, P. F.; SpivaK, M., in preparation

14. TAYLOR, O. R.; Winston, M. L., OTIS, G. W., in preparation

15. WinStON, M. L. (1979) Intra-colony demography and reproductive rate of the Africanized honeybee in South America. Behav. Ecol. Sociobiol. 4:279-292

16. (1980) Seasonal patterns of brood rearing and worker longevity in colonies of the Africanized honey bee (Hymenoptera:Apidae) in South America. J. Kans. ent. Soc. $53: 157-165$

17. Winston, M. L.; Dropkin, J. A.; TAylor, O. R. (1981) Demography and life history characteristics of the honey bee races (Apis mellifera). Oceologia 48:407-413

18. Winston, M. L.; KATZ, S. J. (1982) Longevity of cross-fostered honeybee workers (Apis mellifera) of European and Africanized races. Can. J. Zool. 59: 1571-1575

19. Winston, M. L.; TAYLOR, O. R. (1980) Factors preceding queen rearing in the Africanized honeybee (Apis mellifera) in South America. Insectes Soc. $27: 289-304$

20. Woyke, J. (1973) Experience with Apis mellifera adansonii in Brazil and Poland. Apiacta $8: 115-116$

\section{On the scientific front}

\section{Bees, honey and pollen as indicators of metals in the environment}

It was proved at least as early as 1935 that bees could be killed by the effluent from smelters built in their foraging area ${ }^{7}$. A high arsenic content was found in the honeybees and in pollen they collected. There has been quite a spate of publications recently on wider relationships between bees and trace metals in their environment, and six papers published in 1982 and 1983 are commented on here.

The mineral content of bees, honey, or bee-collected pollen, is now recognized as a useful indicator of the presence of specific minerals within their forage area. High levels of some of the metals are undesirable because of their known or likely toxicity; alternatively some metals may be desirable to the investigator because, if the sources of the minerals can be located, they could perhaps be profitably mined, the bees having been used as preliminary 'prospectors'.

The argument runs like this. Honeybees forage on plants growing in a relatively large area $\left(7 \mathrm{~km}^{2}\right.$ if they fly up to $1.5 \mathrm{~km}$ from the hive). They effectively sample this area for 